\title{
Enthalpy thematic map interpolated with spline method for management of broiler chicken production
}

\author{
Natália C. da Silva ${ }^{1}$, Rodrigo C. Santos ${ }^{2}$, Rafael Zucca ${ }^{2}$, Luciano O. Geisenhoff ${ }^{2}$, Rafaela S. Cesca ${ }^{3} \&$ \\ Juliano Lovatto ${ }^{4}$ \\ ${ }^{1}$ Universidade Estadual de Campinas/Faculdade de Engenharia Agrícola, Campinas, SP, Brasil. E-mail: n-coimbra@hotmail.com - ORCID: 0000-0002- \\ 3703-7136 \\ ${ }^{2}$ Universidade Federal da Grande Dourados/Faculdade de Ciências Agrárias, Dourados, MS, Brasil. E-mail: rodrigocouto@ufgd.edu.br - ORCID: 0000- \\ 0003-4585-9305; rafael-zucca@hotmail.com - ORCID: 0000-0002-6740-7193; lucianogeisenhoff@ufgd.edu.br - ORCID: 0000-0002-5907-5870 \\ ${ }^{3}$ Universidade Federal da Grande Dourados/Faculdade de Ciências Exatas e Tecnologia, Dourados, MS, Brasil. E-mail: rafaela.s.cesca@gmail.com - \\ ORCID: 0000-0002-5059-3575 \\ ${ }^{4}$ Universidade Federal da Grande Dourados/Prefeitura Universitária, Dourados, MS, Brasil. E-mail: julianolovatto@ufgd.edu.br (Corresponding author) \\ - ORCID: 0000-0002-9876-7546
}

\begin{abstract}
Owing to the exponential growth of the human population and problems related to food supply, research focused on finding the most suitable approach to manage and geographically explore the environment using sustainable technologies stand out. The present study aims to produce a consistent interpolation of historical series of enthalpy $(\mathrm{H})$ resulting in a thematic map of enthalpy, using the spline method as a kriging option in areas with few sampling points. The thematic map considers thermal comfort conditions to produce broiler chickens, that could be used as a management tool to reduce power consumption due to the cooling process of the facilities. It was verified that spline is an efficient method to create a suitable thematic maps representations of areas presenting a few sampled units. The geographical representation of enthalpy allowed the evaluation of the environments, concluding that the state of Mato Grosso do Sul, Brazil is inadequate for broiler chickens production without suitable thermal cooling systems. Evidence suggests introduction of aviculture in areas still unexplored, e.g., Chapadão do Sul and Sete Quedas.
\end{abstract}

Key words: map algebra, geo-technology, aviculture, climate changes

\section{Mapa temático de entalpia interpolado com método spline para gerenciamento da produção de frangos de corte}

RESUMO: Devido ao aumento exponencial da população humana e aos problemas relacionados ao suprimento de alimentos, destacam-se pesquisas que buscam encontrar a melhor maneira de gerenciar e explorar geograficamente o meio ambiente, utilizando tecnologias sustentáveis. Este estudo visa possibilitar uma interpolação consistente de séries históricas de entalpia $(\mathrm{H})$, utilizando o método spline como opção de krigagem em áreas com poucos pontos de amostragem, a fim de produzir um mapa temático da entalpia, considerando as condições de conforto térmico para produzir frangos de corte, que poderá ser utilizado como ferramenta de manejo, visando reduzir o consumo de energia devido ao processo de resfriamento das instalações. Verificou-se que spline é um método eficiente para criar uma representação adequada de mapas temáticos de áreas que apresentam poucas unidades amostradas. A representação geográfica de entalpia permitiu a avaliação dos ambientes, concluindo que o Mato Grosso do Sul é um Estado onde a produção de frangos de corte torna-se inviável sem sistemas apropriados de resfriamento térmico, o que corrobora a sugestão de introdução da avicultura em áreas ainda inexploradas, como Chapadão do Sul e Sete Quedas.

Palavras-chave: álgebra de mapa, geotecnologia, avicultura, mudanças climáticas 


\section{INTRODUCTION}

Inadequate climatic conditions reduce the productivity and reproduction performance of animals, especially in tropical regions. According to Mazahreh et al. (2019), climate databases created using Geographic Information System (GIS) enable to perform the bioclimatic zonation of a region, supporting the supervision of eventual changes and acting as an environment tool used to improve agricultural production.

Dornellas et al. (2017) used map algebra to calculate parameters which characterize spatial dependence structures of climatic variables through the elaboration of thematic maps that use the interpolation method. Greco et al. (2018) considered that when several environmental studies are involved, an alternative to kriging techniques is the spline method, since it interpolates the function $f(x)$ in groups presenting few knots.

According to Mitchell et al. (2018), when thematic maps are used to assess the ecosystem and to perform spatial planning correctly, it is important to verify the accuracy in which they have been produced to ensure suitability for the intended purpose. Thus, map algebra stands out as a management tool for the animal production sector.

The world production of broiler chickens is estimated at 103.5 million tons of chicken meat in 2018, and the thermal stress causes economic losses from US\$ 128 to US\$ 165 million per year, only in the poultry industry. In this sense, innovations are increasingly necessary to improve the quality of products (Nawab et al., 2018).

Considering its importance in the Brazilian agriculture production and the reduced number of climate stations distributed over its large territorial extension, the state of Mato Grosso do Sul, Brazil can be used as a reference to evaluate the consistency of the spline method as an interpolator. Therefore, this research aimed to use the spline method to interpolate historical series of enthalpy means from summer periods in the state of Mato Grosso do Sul, Brazil to produce a thematic map of the enthalpy, providing an overview of the most suitable areas for production, considering energy expenditure for thermal cooling.

\section{Material ANd Methods}

The study was performed in the Mato Grosso do Sul (MS) state, Brazil $\left(17^{\circ} 0^{\prime} 00^{\prime \prime} \mathrm{W}, 58^{\circ} 0^{\prime} 00^{\prime \prime} \mathrm{S}\right.$, altitude between 200 and $600 \mathrm{~m}$ ), with climate Monsoon Am, dry winter, according to Köppen classification, annual mean precipitation of $1500 \mathrm{~mm}$ and annual mean temperature of $22^{\circ} \mathrm{C}$ (Alvares et al., 2013).

The thematic map has been produced based on the information provided by the Instituto Nacional de Meteorologia (INMET, 2018). In this context, the general of the 28 automated weather stations (Figure 1) in MS, Brazil has been established based on the hourly averages of the temperature of air $(\mathrm{Ta})$ and the relative humidity of air (UR) - recorded $24 \mathrm{~h}$ a day, through official summer periods (90 days each), from 2001 to 2017.

Data provided by INMET were registered in electronic spreadsheets to be statistically assessed and read by GIS, in database format.

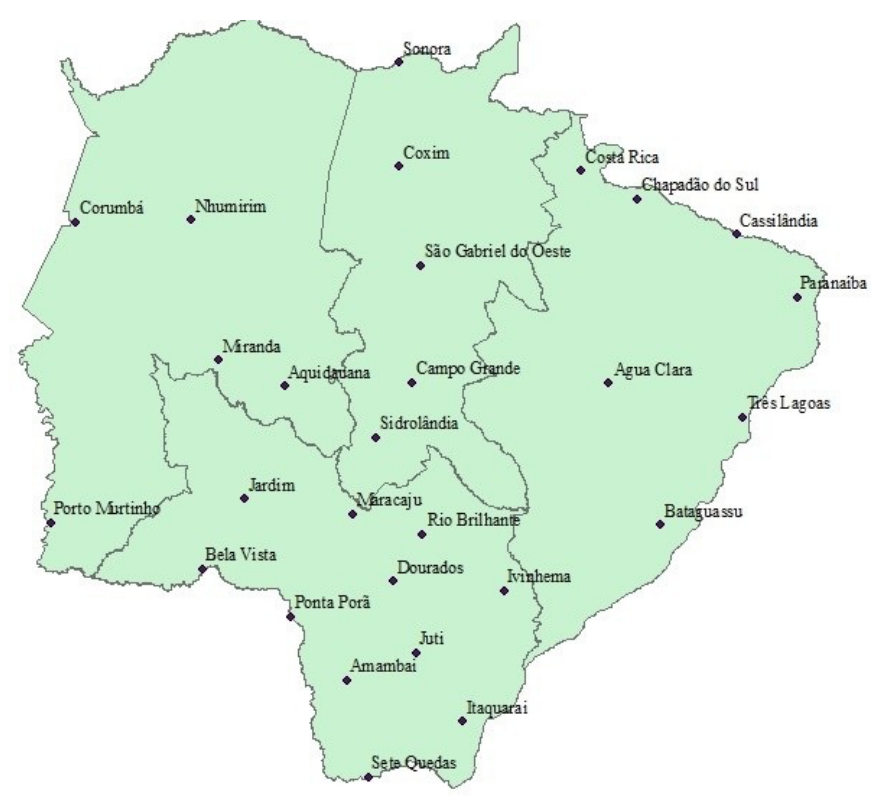

Figure 1. Mesoregions map showing INMET automated positions of the station in the state of Mato Grosso do Sul (MS), Brazil

Using the software Minitab $17^{\circ}$ (Minitab, 2014), the maximum and minimum means of Ta have been analyzed, considering each summer period from 2001 to 2017. The mean, median, variance, kurtosis, and asymmetry have been estimated.

Theoretical estimators and the description of the spatial dependence structure are influenced by geodesic distance, shape, and sample size. Thus, since the geographical place presents few heterogeneous samples (different automated weather stations), the spline method adopted to be used in the research does not use a high order polynomial to interpolate data. The spline template adopted had a degree of one, which according to Kunoth et al. (2018), can be defined as a set of linear functions, where:

$$
\begin{gathered}
f(x)=f\left(x_{0}\right)+m_{0}\left(x-x_{0}\right), \text { for } x_{0} \leq x \leq x_{1} \\
f(x)=f\left(x_{1}\right)+m_{1}\left(x-x_{1}\right), \text { for } x_{1} \leq x \leq x_{2} \\
f(x)=f\left(x_{n-1}\right)+m_{n-1}\left(x-x_{n-1}\right), \text { for } x_{n-1} \leq x \leq x_{n}
\end{gathered}
$$

where:

$f(x)$ - linear interpolator polynomial between points $x_{0}$ and $x_{n-1}$;

$\mathrm{x}_{0,}, \mathrm{x}_{1}, \ldots, \mathrm{x}_{\mathrm{n}-1}$ - consecutive points of interpolated geographical location;

$m_{i} \quad$ - angular coefficient of the straight line that connects the dots in the range $m_{0} \leq m_{i} \leq m_{n-1}$;

$\mathrm{n} \quad-1,2,3, \ldots$, natural numbers, each point in the range;

$\mathrm{m}_{0}$ - first point in the range considered;

$\mathrm{m}$ - first point in the range considered; and,

$$
m_{i}=\frac{f\left(x_{i+1}\right)-f\left(x_{i}\right)}{x_{i+1}-x_{i}} \text {, with } 0 \leq i \leq n-1
$$

The function $\mathrm{f}(\mathrm{x})$ can be calculated using these equations at any given point between $x_{0}$ and $x_{n}$. 
The general mean spatialization of the local meteorological data Ta and UR has been calculated using function Topo to Raster from ArcGis Desktop ${ }^{\oplus}$ (ESRI, 2015) as the interpolator of the 28 automated stations in MS, Brazil. The general mean index $\mathrm{H}$ for each station has been established by Raster calculator, adopting a similarity parameter of 32 pixels and using Eq. 5, proposed by Barbosa Filho et al. (2007).

$$
\mathrm{H}=\left[6.7+0.243 \mathrm{Ta}+\left(\frac{\mathrm{UR}}{100} 10^{\frac{7.5 \mathrm{Ta}}{237.3+\mathrm{Ta}}}\right)\right] 4.18
$$

where:

$$
\begin{array}{ll}
\mathrm{H} & \text { - enthalpy, } \mathrm{kJ} \mathrm{kg}^{-1} \mathrm{dry} \text { air; } \\
\mathrm{Ta} & \text { - air temperature, }{ }^{\circ} \mathrm{C} \text {; and, } \\
\mathrm{UR} & \text { - air relative humidity, \%. }
\end{array}
$$

Spatial dependence analysis was performed according to Dalchiavon et al. (2012), who use the ratio between nugget effect $(\mathrm{C} 0)$ and baseline $(\mathrm{C} 0+\mathrm{C} 1)$ - where $\mathrm{C} 1 /(\mathrm{C} 0+\mathrm{C} 1)$ - to classify the Spatial Dependence Index (SDI) as very low (SDI $<20 \%)$, low $(20 \leq \mathrm{SDI}<40 \%)$, medium $(40 \leq \mathrm{SDI}<60 \%)$, high $(60 \leq \mathrm{SDI}<80 \%)$ and very high $(80 \leq \mathrm{SDI} \leq 100 \%)$.

The mean enthalpy $(\mathrm{H})$ thematic map was organized with ranges comprised of comfort and stress levels, established by Barbosa Filho (2008), considering the 6-weeks poultry, according to Table 1 .

As an enthalpy $(\mathrm{H})$ thematic map interpolated with the spline method has been created, geosciences and environment principles can be used to assess the thermal comfort conditions of the region studied, and to determine if the technique used elicits a precise management tool to this productive sector.

Table 1. Comfort ranges of enthalpy, considering the production of the 6-weeks fowls

\begin{tabular}{cc}
\hline $\begin{array}{c}\text { Enthalpy } \mathbf{( H )} \\
\mathbf{( k J ~ k g - 1}^{-1} \text { dry air) }\end{array}$ & $\begin{array}{c}\text { Comfort } \\
\text { situation }\end{array}$ \\
$37.4-52.1$ & NORMAL \\
$52.2-63.0$ & CAUTION \\
$63.1-72.6$ & WARNING \\
$\geq 72.7$ & DANGER \\
\hline
\end{tabular}

\section{Results AND Discussion}

According to Table 2, the maximum mean value of the temperature of air (Ta) observed in Mato Grosso do Sul state, Brazil, during the summer periods studied was $35.17^{\circ}$ in Sonora (2013-2014), and de minimum, in Rio Brilhante, was $16.73^{\circ}$ (2003-2004). The slightest temperatures among the minimum ones were recorded since the means were calculated considering daily values, probably recorded during nighttime.

Studies reported by Ibtisham et al. (2018) noticed a mean value reduction of $16.4 \%$ in the chicken feed consumed by the animals housed in an unsuitable environment when compared to those housed in thermoneutral ambiance, in which air temperature was around $20{ }^{\circ} \mathrm{C}$. Therefore, Table 2 shows that, historically, Mato Grosso do Sul state, Brazil presents an unsuitable environment for poultry production.

Maximum mean of the relative air humidity (UR) during the summer periods was $92.89 \%$ in Bataguassu (2007-2008) and the minimum mean $34.60 \%$ in São Gabriel do Oeste (2001-2002) (Table 2). Studies reported by Rico-Contreras et al. (2017) state that behavior variables are influenced by UR, increasing stress behavior occurrences in very humid environments, causing significant losses. According to Xiong et al. (2017), the UR recommended for broiler chickens ranges from 50 to $70 \%$. Thus, the state of Mato Grosso do Sul, Brazil presents UR out of the comfort zone, which should be regulated by controlling ambiance procedures.

Table 3 presents the descriptive statistics of maximum (Tmax) and minimum (Tmin) temperatures, performed based on the assessment of their effects through mean, median, variance, kurtosis, and asymmetry.

From Table 3, it can be observed that the mean and median of Tmax are higher than it is recommended for broiler chicken production. Therefore, the state of Mato Grosso do Sul, Brazil presents, historically, an unsuitable thermal environment, which requires air-conditioning during summers.

A coefficient of variation is considered low if presents values less than $12 \%$; medium, if ranging from 12 to $24 \%$; and high, if higher than 24\% (Massari et al., 2016). Thus, the coefficient of

\begin{tabular}{|c|c|c|c|c|c|c|c|c|}
\hline \multirow{2}{*}{$\begin{array}{l}\text { Summer } \\
\text { periods }\end{array}$} & \multicolumn{8}{|c|}{ Climatic variables } \\
\hline & $\begin{array}{c}T \max \\
\text { ( } \mathrm{C} \text { C) }\end{array}$ & City & $\begin{array}{l}\operatorname{Tmin} \\
\left.\text { ( }{ }^{\circ} \mathrm{C}\right)\end{array}$ & City & $\begin{array}{c}\text { URmax } \\
(\%)\end{array}$ & City & $\begin{array}{c}\text { URmin } \\
(\%)\end{array}$ & City \\
\hline 2001_2002 & 32.67 & Coxim & 17.13 & Chapadão do Sul & 91.67 & Aquidauana & 34.60 & São Gabriel do Oeste \\
\hline 2002_2003 & 32.98 & Corumbá & 17.01 & Costa Rica & 91.84 & Corumbá & 37.40 & Itaquirai \\
\hline 2003_2004 & 33.22 & Sonora & 16.73 & Rio Brilhante & 89.26 & Porto Murtinho & 38.40 & Maracaju \\
\hline 2004_2005 & 32.81 & Coxim & 17.23 & Chapadão do Sul & 92.01 & Nhumirim & 34.83 & Amambai \\
\hline 2005_2006 & 32.86 & Aquidauana & 17.42 & Amambai & 90.83 & Corumbá & 39.59 & Maracaju \\
\hline $2006 \_2007$ & 32.98 & Miranda & 17.94 & Maracaju & 92.08 & Miranda & 39.20 & Coxim \\
\hline 2007_2008 & 33.04 & Corumbá & 17.61 & Costa Rica & 92.89 & Bataguassu & 40.05 & Ponta Porã \\
\hline 2008_2009 & 33.92 & Aquidauana & 18.22 & Rio Brilhante & 90.91 & Porto Murtinho & 38.33 & Cassilândia \\
\hline $2009-2010$ & 34.03 & Sonora & 18.08 & Amambai & 91.81 & Sonora & 36.62 & Juti \\
\hline 20102011 & 33.93 & Bataguassu & 17.52 & Ponta Porã & 91.65 & Porto Murtinho & 37.30 & Paranaíba \\
\hline 20112012 & 33.52 & Bela Vista & 17.04 & Sete Quedas & 90.06 & Nhumirim & 40.10 & Coxim \\
\hline 20122013 & 34.46 & Miranda & 17.52 & Sete Quedas & 89.98 & Miranda & 38.00 & Coxim \\
\hline 2013 & 35.17 & Sonora & 17.87 & Ponta Porã & 92.82 & Nhumirim & 39.38 & Amambai \\
\hline 20142015 & 34.44 & Miranda & 17.14 & Amambai & 92.39 & Aquidauana & 41.08 & Maracaju \\
\hline 20152016 & 34.11 & Três Lagoas & 17.45 & Sete Quedas & 93.41 & Bataguassu & 36.98 & Juti \\
\hline $2016 \_2017$ & 34.25 & Aquidauana & 17.41 & Amambai & 93.18 & Porto Murtinho & 37.68 & Água Clara \\
\hline
\end{tabular}
variation was recorded as high for Tmax (54.80\%) and medium

Table 2. Mean maximum (Tmax) and minimum (Tmin) temperatures values and mean maximum (URmax) and minimum (URmin) relative air humidity during the summer periods of 2001_2002 and 2016_2017 
Table 3. Descriptive statistics of maximum (Tmax) and minimum (Tmin) temperatures in different summer periods

\begin{tabular}{lcc}
\hline & Tmax & Tmin \\
\cline { 2 - 3 } Number of stations & 28 & ( \\
Number of summers & 16 & 28 \\
Mean & 33.65 & 16 \\
Median & 33.72 & 17.46 \\
Coefficient of variation (\%) & 54.80 & 17.44 \\
Standard error & 0.74 & 17.13 \\
Kurtosis & -0.80 & 0.41 \\
Asymmetry & 0.38 & -0.50 \\
\hline
\end{tabular}

for Tmin (17.13\%). Considering that variance shows how far from the mean the values are, it can be affirmed that the thermal amplitude around Tmax were higher, which is confirmed by the values for both differences between mean and median of Tmax and Tmin values.

The smaller the standard deviation, the more homogeneous it is a sample. That is, Tmax thermal amplitude was higher than Tmin. From the mean environment variables of summer periods in the state of Mato Grosso do Sul, Brazil registered in Table 2, it can be observed that there was no climate variation pattern through the years. However, heat islands were observed. According to studies performed by De-Salamanca et al. (2017), the presence of heat islands is characterized by thermal amplitude variation of environments, which suggests a process of adaptation to climate changes.

Kurtosis measures indicate the concentration degree of a set of values distributed around a central value. Both cases are called Platykurtic (kurtosis $<0$ ), and Tmin is closer to ordinary distribution values. Silva et al. (2017) state that when thermal variable distribution and indexes in space are random, they present a low spatial dependence degree.

Positive values of Tmax asymmetry (0.38) and Tmin asymmetry (0.26) indicate that the right tail is larger than the left one. This can be regarded as a positive oscillation of temperatures during the period studied, where Tmax increased more than Tmin.

Due to the small number of climate stations in the state of Mato Grosso do Sul, Brazil, Ta and UR data used for enthalpy $(\mathrm{H})$ calculation, presented a great spatial variability. According to Tang et al. (2018), the smaller the spatial dependence, the higher is the nugget effect over data oscillation consequently, the worse kriging estimates when producing the maps. This fact vouches for spline method usage in this mapping research with few sampling points.

Based on the spatial dependence analysis, the semivariograms fitted the presented mean SDI $(40 \leq$ SDI $<60 \%)$. Similar results were elicited by Barbieri et al. (2016), who detected more incidence of mean SDI values among the variables analyzed, considering the automated weather stations when working with the climate classification in Mato Grosso Sul, another Brazilian state. The results show low spatial dependence.

The thematic map represented by Figure 2 was produced interpolating mean enthalpy $(\mathrm{H})$ values, from the summer periods under analysis with the spline method and curves following spherical and exponential patterns. Based on spatialization analysis using geostatistical methods, Kestring et al. (2015) stated that places where spatial dependence is not

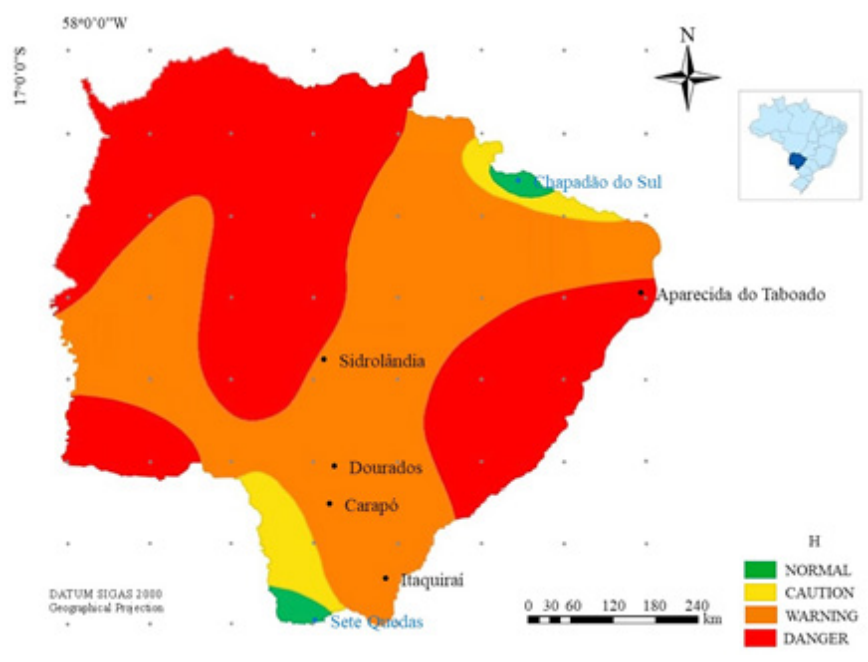

Figure 2. The enthalpy thematic map presenting the mean of summer periods from 2001 to 2017 in the state of Mato Grosso do Sul, Brazil

high, kriging should be avoided, and where it is medium, the best models to adjust curves in thematic maps are the spherical and the exponential.

The enthalpy represents an exothermal reaction and can be used as a tool to indicate the amount of thermal energy in the air, over the animal, and to be removed from the ambiance to improve comfort conditions. It also provides welfare rates and productive and reproductive outcomes, assessing management decision-making (Fournel et al., 2017).

Figure 2 shows the different comfort levels in poultry production in the state of Mato Grosso do Sul, Brazil, based on the mean $\mathrm{H}$ index, presented in different colors according to a specific stress situation: comfort, caution, warning, and danger. Similar to research reported by Santana et al. (2018), the obtained values of $\mathrm{H}$ classified as caution and warning, causing the reduction of: feed and water consumption and production of endogenous heat and feed conversion, directly affecting poultry production.

As Mato Grosso do Sul, Brazil is geographically well located and presents an elevated grain production, it has great potential to advance in poultry production. However, one of the major barriers is the inadequate climate. Five major production centers are located in the cities of Sidrolândia, Dourados, Caarapó, Itaquiaraí, and Aparecida do Taboado, and due to demand rise, there is a possibility of expanding poultry sector to other areas still unexplored (FAMASUL, 2018).

It can be observed from Figure 2 that among the major broiler chicken producers, in MS, Brazil Sidrolândia, Dourados, Caarapó, and Itaquiraí face a warning situation (from 63.1 to $72.6 \mathrm{~kJ} \mathrm{~kg}^{-1}$ dry air). Aparecida do Taboado is classified as in a dangerous situation ( $\geq 72.7 \mathrm{~kJ} \mathrm{~kg}^{-1}$ dry air). Rovaris et al. (2014) suggest using comfort indexes with parameters to activate and control thermal cooling systems and mitigate external environment effects overproduction to obtain a more effective environment control.

According to the thematic map presented in Figure 2, from the climatic point of view, Chapadão do Sul (North) and Sete Quedas (South) present a more adequate climate to broiler chicken production than the other cities, with mean $\mathrm{H}$ considered normal (from 37.4 to $52.1 \mathrm{~kJ} \mathrm{~kg}^{-1}$ dry air). This 
indicates that these regions are new productive centers since they require less power consumption for facility cooling, which causes costs reduction. Constantino et al. (2018) demonstrated that the intensive production of broiler chickens consumes high levels of power, when aiming the welfare of animals. This endorses expanding poultry to areas with a more appropriate climate.

When using $\mathrm{H}$ to assess comfort, it can be observed from Figure 2 that most parts of the regions were classified as warning and danger levels. Tavares et al. (2016) also used $\mathrm{H}$ to map comfort levels in Brazil and concluded that most regions were classified as discomfort levels. This confirms that $\mathrm{H}$ index thematic maps used to analyze thermal environments are also useful to sustainably manage the production.

\section{Conclusions}

1. Spline method is an adequate GIS tool for interpolating historical series and generating thematic maps of the state of Mato Grosso do Sul, Brazil.

2. It was observed that there was no pattern of climate variation over the years, but it is possible to state that there were heat pockets with historical highs concentrated in the Northern Mato Grosso do Sul, Brazil.

3. Based on the enthalpy thematic map produced in this study, it can be concluded that the five major centers producing broiler chickens in the state of Mato Grosso do Sul, Brazil are located in areas where climate is inadequate.

4. From the data, places that have not yet been explored, may be suggested for the introduction of aviculture as Chapadão do Sul (North) and Sete Quedas (South).

\section{Literature Cited}

Alvares, C. A.; Stape, J. L.; Sentelhas, P. C.; Moraes, G. L.; Sparavek, G. Köppen's climate classification map for Brazil. Meteorologische Zeitschrift, v.22, p.711-728, 2013. https://doi.org/10.1127/09412948/2013/0507

Barbieri, J. D.; Dallacort, R.; Santi, A.; Faria Junior, C. A.; Freitas, P. S. L. de; Araújo, D. V. de. Classificação de risco climático para o cultivo do amendoim no Estado de Mato Grosso. Revista Espacios, v.37, p.25-36, 2016.

Barbosa Filho, J. A. D. Caracterização quantiqualitativa das condições bioclimáticas e produtivas nas operações pré-abate de frangos de corte. Piracicaba: ESALQ/USP. 2008. 174p. Tese de Doutorado

Barbosa Filho, J. A. D.; Silva, I. J.; Silva, M. A.; Silva, C. J. Avaliação dos comportamentos de aves poedeiras utilizando sequência de imagens. Engenharia Agrícola, v.27, p. 93-99, 2007. https://doi. org/10.1590/S0100-69162007000100002

Constantino, A.; Fabrizio, E.; Ghiggini, A.; Bariani, M. Climate control in broiler houses: A thermal model for the calculation of the energy use and indoor environmental conditions, Energy and Buildings, v.169, p.110-126, 2018. https://doi.org/10.1016/j. enbuild.2018.03.056

Dalchiavon, F. C.; Carvalho, M. de P. e; Andreotti, M.; Montanari, R. Variabilidade espacial de atributos da fertilidade de um Latossolo Vermelho Distroférrico sob sistema plantio direto. Revista Ciência Agronômica, v.43, p.453-461, 2012. https://doi. org/10.1590/S1806-66902012000300006
De-Salamanca, A. E.; Sierra, R. D.; Aranda, R. M. M.; Santos, M. J. Environmental impacts of climate change adaptation. Environmental Impact Assessment Review, v.64, p.87-96, 2017. https://doi.org/10.1016/j.eiar.2017.03.005

Dornellas, P. da C.; Seabra, V. da S.; Xavier, R. A.; Silva, R. M. da. Estimativa de perdas de solo na bacia do alto Rio Paraíba, região semiárida do Estado da Paraíba. OKARA: Geografia em Debate, v.11, p.338-350, 2017. https://doi.org/10.22478/ufpb.1982$3878.2017 \mathrm{v} 11 \mathrm{n} 2.37658$

ESRI - Enviromental Systems Research Institute. ArcGis for Windows Version $10.3^{\circ}$. Licence type ArcInfo. [S.I]: ESRI -, 2015.

FAMASUL - Federação da Agricultura e Pecuária de Mato Grosso do Sul. Retrospectiva agro 2017: Um balanço do agronegócio de Mato Grosso do Sul em 2017. Available on: <http://www. famasul.com.br/famasul>. Accessed on: Jul. 2018.

Fournel, S.; Rousseau, A. N.; Laberge, B. Rethinking environment control strategy of confined animal housing systems through precision livestock farming. Biosystems Engineering, v.155, p.96123, 2017. https://doi.org/10.1016/j.biosystemseng.2016.12.005

Greco, F.; Ventrucci, M.; Castelli, E. P-spline smoothing for spatial data collected worldwide. Spatial Statistics, v.27, p.1-17, 2018. https://doi.org/10.1016/j.spasta.2018.08.008

Ibtisham, F.; Zhao, Y.; Nawab, A.; Liguang, H.; Wu, J.; Xiao, M.; Zhao, Z.; An, L. The effect of high temperature on viability, proliferation, apoptosis and anti-oxidant status of chicken embryonic fibroblast cells. Brazilian Journal of Poultry Science, v.20, p.463-470, 2018. https://doi.org/10.1590/1806-9061-20170685

INMET - Instituto Nacional de Meteorologia. Available on: <http:// www.inmet.gov.br/>. Accessed on: Jul. 2018.

Kestring, F. B. F.; Guedes, L. P. C.; Bastiani, F.; Uribe-Opazo, M. A. Thematic maps comparison of different sampling grids for soybean productivity. Engenharia Agrícola, v.35, p.733743, 2015. https://doi.org/10.1590/1809-4430-Eng.Agric. v35n4p733-743/2015

Kunoth, A.; Lyche, T.; Sangalli, G.; Capizzano, S. S. Splines and PDEs: From approximation theory to numerical linear algebra. Cetraro: Springer, 2018. 330p. https://doi.org/10.1007/978-3319-94911-6

Massari, J. M.; Moura, D. J.; Curi, T. M. R. C.; Vercellino, R. A.; Medeiros, B. B. L. Zoning of environmental conditions inside a wean-to-finish pig facility. Engenharia Agrícola, v.36, p.739748, 2016. https://doi.org/10.1590/1809-4430-Eng.Agric. v36n5p739-748/2016

Mazahreh, S.; Bsoul, M.; Hamoor, D. A. GIS approach for assessment of land suitability for different land use alternatives in semi arid environment in Jordan: Case study (Al Gadeer AlabyadMafraq). Information Processing in Agriculture, v.6, p.91-108, 2019. https://doi.org/10.1016/j.inpa.2018.08.004

MINITAB - I. MINITAB Release 17. Statistical software for Windows. State College: Minitab Inc., 2014.

Mitchell, P. J.; Downie, A. L.; Diesing, M. How good is my map? A tool for semi-automated thematic mapping and spatially explicit confidence assessment. Environmental Modelling \& Software, v.108, p.111-122, 2018. https://doi.org/10.1016/j. envsoft.2018.07.014 
Nawab, A.; Ibtisham, F.; Li, G.; Kieser, B.; Wu, J.; Liu, W.; Zhao, Y.; Nawab, Y.; Li, K.; Xiao, M.; An, L. Heat stress in poultry production: Mitigation strategies to overcome the future challenges facing the global poultry industry. Journal of Thermal Biology, v.78, p.131139, 2018. https://doi.org/10.1016/j.jtherbio.2018.08.010

Rico-Contreras, J. O.; Aguilar-Lasserre, A. A.; Méndez-Contreras, J. M.; López-Andrés, J. J.; Cid-Chama, G. Moisture content prediction in poultry litter using artificial intelligence techniques and Monte Carlo simulation to determine the economic yield from energy use. Journal of Environmental Management, v.202, p.254-267, 2017. https://doi.org/10.1016/j.jenvman.2017.07.034

Rovaris, E.; Corrêa, G. da S. S.; Corrêa, A. B.; Caramori Junior, J. C.; Luna, U. V. de; Assis, S. D. de. Desempenho de frangos de corte criados em aviários dark house versus convencional. Publicações em Medicina Veterinária e Zootecnia, v.8, p.21732291, 2014. https://doi.org/10.22256/pubvet.v8n18.1778

Santana, M. H. M.; Saraiva, E. P.; Costa, F. G. P.; Figueiredo Júnior, J. P.; Santana, A. M. M. de A.; Alves, A. R. Ajuste dos níveis de energia e proteína e suas relações para galinhas poedeiras em diferentes condições térmicas. Publicações em Medicina Veterinária e Zootecnia, v.12, p.1-12, 2018. https://doi.org/10.22256/pubvet.v12n1a20.1-12
Silva, F. J. da; Oliveira, C. A. A. de; Almeida, L. da S.; Lima, L. P. de; Guimarães, E. C. Variabilidade espacial da resistência do solo à penetração e produtividade do milho. Journal of Neotropical Agriculture, v.4, p.77-84, 2017. https://doi.org/10.32404/rean. v4i3.1625

Tang, Y.; Zhang, J.; Jing, L.; Gao, H. Geostatistical modelling of spatial dependence in area-class occurrences for improved object-based classifications of remote-sensing images. ISPRS Journal of Photogrammetry and Remote Sensing, v.141, p.219-236, 2018. https://doi.org/10.1016/j. isprsjprs.2018.05.003

Tavares, G. F.; Carnevskis, E. L.; Schiassi, L.; Carlos Filho, R.; Miranda, K. O. S.; Miranda, J. H. de. Bioclimatic zoning for beef cattle in Brazil with the aid of intelligent systems. Journal of Animal Behaviour and Biometeorology, v.4, p.116-123, 2016. https://doi.org/10.14269/2318-1265/jabb. v4n4p116-123

Xiong, Y.; Meng, Q.; Gao, J.; Tang, X.; Zhang, H. Effects of relative humidity on animal health and welfare. Journal of Integrative Agriculture, v.16, p.1653-1658, 2017. https://doi.org/10.1016/ S2095-3119(16)61532-0 